\title{
The isotropic fractionator provides evidence for differential loss of hippocampal neurons in two mouse models of Alzheimer's disease
}

\author{
Hannah Brautigam ${ }^{1,2,5}$, John W Steele ${ }^{2,6,7}$, David Westaway ${ }^{8}$, Paul E Fraser ${ }^{9}$, Peter H St George-Hyslop ${ }^{9,10}$,
} Sam Gandy ${ }^{2,3,4,5,6}$, Patrick R Hof f, $^{1,5}$ and Dara L Dickstein ${ }^{1,2,5,11^{*}}$

\begin{abstract}
Background: The accumulation of amyloid beta $(A \beta)$ oligomers or fibrils is thought to be one of the main causes of synaptic and neuron loss, believed to underlie cognitive dysfunction in Alzheimer's disease (AD). Neuron loss has rarely been documented in amyloid precursor protein (APP) transgenic mouse models. We investigated whether two APP mouse models characterized by different folding states of amyloid showed different neuronal densities using an accurate method of cell counting.

Findings: We examined total cell and neuronal populations in Swedish/Indiana APP mutant mice (TgCRND8) with severe A $\beta$ pathology that includes fibrils, plaques, and oligomers, and Dutch APP mutant mice with only A $\beta$ oligomer pathology. Using the isotropic fractionator, we found no differences from control mice in regional total cell populations in either TgCRND8 or Dutch mice. However, there were 31.8\% fewer hippocampal neurons in TgCRND8 compared to controls, while no such changes were observed in Dutch mice.

Conclusions: We show that the isotropic fractionator is a convenient method for estimating neuronal content in milligram quantities of brain tissue and represents a useful tool to assess cell loss efficiently in transgenic models with different types of neuropathology. Our data support the hypothesis that TgCRND8 mice with a spectrum of $A \beta$ plaque, fibril, and oligomer pathology exhibit neuronal loss whereas Dutch mice with only oligomers, showed no evidence for neuronal loss. This suggests that the combination of plaques, fibrils, and oligomers causes more damage to mouse hippocampal neurons than $A \beta$ oligomers alone.
\end{abstract}

Keywords: Alzheimer's disease, Mouse models, Amyloid beta (A $\beta$ ), Isotropic fractionator, Neuronal loss

\section{Findings}

Alzheimer's disease (AD) is a progressive neurodegenerative disorder characterized by the presence of extracellular amyloid beta $(A \beta)$ plaques, neurofibrillary tangles, and severe loss of synapses and neurons [1]. One of the limitations of $\mathrm{AD}$ mouse models has been the absence of cell loss in many of them [2-4], although systematic head-to-head comparison of neuronal loss in mouse models has been hindered by the fact that highquality morphometry is not routinely available or

\footnotetext{
* Correspondence: dara.dickstein@mssm.edu

${ }^{1}$ Fishberg Department of Neuroscience, Icahn School of Medicine at Mount Sinai, New York, NY 10029, USA

${ }^{2}$ Friedman Brain Institute, Icahn School of Medicine at Mount Sinai, New York, NY 10029, USA

Full list of author information is available at the end of the article
}

achieved. Furthermore, there are a number of nonstereologic approaches, prone to observer biases, which are often employed but fail to produce comparable results, within a laboratory as well as across studies. As a result, reliable quantification of neuronal loss has not been routinely included in the characterization of mouse models. Absence of data on neuronal loss reduces the usefulness in specifying how particular transgenes and interventions impact neuronal integrity. Here, we examined changes in total cell (i.e., neurons and glia) and total neuronal numbers and densities in two mouse models of AD harboring different APP mutations and exhibiting different panoplies of $A \beta$ biophysical phenotypes: the TgCRND8 mouse and the Dutch APP mouse. TgCRND8 mice express the Swedish (K670M/N671L)

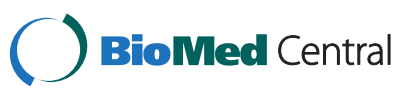


and Indiana (V717F) APP mutations, and exhibit increases in total production of $A \beta$ and in the $A \beta_{42} / A \beta_{40}$ ratio, leading to accumulation of intraneuronal $A \beta, A \beta$ amyloid plaques, soluble oligomeric $A \beta(o A \beta)$, and insoluble fibrillar $A \beta$ (fA $\beta$ ) [5]. The Dutch mouse expresses the E693Q mutation that favors the production of oA $\beta$ over $\mathrm{fA} \beta$ and accumulates intraneuronal $A \beta$ and oA $\beta$ [3] (Additional file 1: Table S1; Figure 1).

We employed the isotropic fractionator method [6], and quantified cell and neuronal populations in these two different APP mouse lines that we predicted would demonstrate different levels of neuronal integrity. When comparing our total cell numbers to published estimates from wildtype mouse brains, we found that they were comparable to those reported for whole brain using the isotropic fractionator [7], and for specific brain regions such as the cerebellum, as estimated by isotropic fractionator and flow cytometry [8], and the hippocampus as assessed by traditional stereology [9-12] (Table 1). When assessing total cell and neuron populations, we found no differences in total and regional brain weights between transgenic mice and their respective littermates. We also did not find any differences in total cell counts or densities between TgCRND8 mutant APP mice and controls (Figure 2A-F). However, we observed significantly fewer (31.8\%) hippocampal neurons between TgCRND8 mutant APP mice and their non-transgenic littermates $\left(t_{(12)}=2.391, \mathrm{p}=0.033\right.$; Figure $\left.2 \mathrm{H}\right)$. No significant differences were observed in total neuronal counts or densities in neocortex or cerebellum (Figure 2G, I-L). When we studied Dutch mutant APP mice, we found no significant differences from controls in total cell count, neuronal cell count, cell density, or neuronal density (Figure 2). We did not observe neuronal density changes in the neocortex, perhaps because of region- or even layer-specific vulnerability of select neuronal populations. We did not assess neuron numbers in specific neocortical regions and, as such, any locally restricted loss may have been undetected. We also analyzed mice at only one time point and it is possible that neocortical neuronal loss may appear at later stages.

Aberrant accumulation of brain $\mathrm{A} \beta$ over decades has been proposed to result in synaptic and neuronal loss associated with the progression of $\mathrm{AD}$ (for review see [13]). Evidence indicates that accumulation of soluble $\mathrm{oA} \beta$ relates to cognitive impairment in AD patients [14] and $\mathrm{AD}$ mouse models $[2,3,15]$. However, the possibility that the severity of neurotoxicity and neuronal loss may be related to levels of $A \beta$ solubility or confirmation (oA $\beta$ or $f A \beta)$ remains unclear. Using high-resolution $3 D$ reconstructions, intraneuronal accumulation of $\mathrm{fA} \beta$ has been observed by some investigators who proposed that this $\mathrm{fA} \beta$ leads to the disruption and degeneration of spines and neurites, and ultimately to neuronal death [16], even though other investigators have reported that $\mathrm{oA} \beta$ alone is sufficient for behavioral dysfunction [15].

Importantly, other studies have demonstrated reduced neuron densities in various lines of APP mice following onset of plaque pathology. These observations were primarily derived from the hippocampus and are similar in magnitude to the loss we report in TgCRND8 mice, albeit using different counting methods (Table 1). Using a stereologic approach, Calhoun et al. (1998) found a $\sim 25 \%$ loss of CA1 neurons in TgAPP23 mice, while Schmitz et al. (2004) found a $\sim 30 \%$ loss of neurons in the CA1-3 regions in an APP/PS1 double mutant mouse, and Breyhan et al. (2009) found a 33\% loss of CA1 pyramidal neurons in APP/PS1 knock-in mice. Our results indicate that, in wildtype mice, estimates derived from the isotropic fractionator are generally comparable to stereologic estimates. Most importantly, we observed an apparent neuronal loss in TgCRND8 mice that form

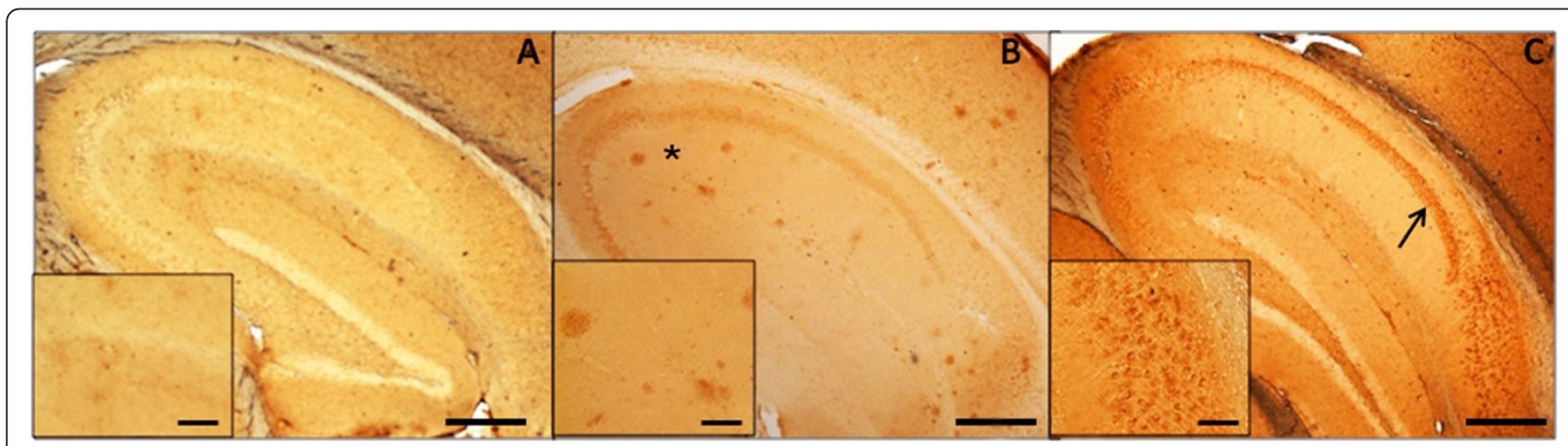

Figure 1 APP/A $\beta$ pathology in the hippocampus of TgCRND8 mutant APP and Dutch mutant APP transgenic mice. A $\beta$ and APP species were visualized using the 6 E10 antibody. Extracellular amyloid plaques (asterisk) are evident in (B) TgCRND8 APP transgenic mice (3.5 months old), while (C) Dutch mutant APP (17 months old) exhibit intracellular APP/Aß-like immunoreactivity (APP/Aß-LIR; arrow). No APP/A -LIR is seen when $6 \mathrm{E} 10$ is used to immunostain brain of a wild type mouse (A). Inset panels represent higher magnification of $6 \mathrm{E} 10$ immunoreactivity of plaques in TgCRND8 mutant APP mice and intracellular APP/Aß-LIR in Dutch mutant APP mice. Scale bars represent 500 um. Scale bars in insets represent $100 \mu \mathrm{m}$. 
Table 1 Summary of cell and neuron counts from different studies according to brain region and counting method

\begin{tabular}{|c|c|c|c|c|c|}
\hline Method & Genetic background & Brain region & $\begin{array}{l}\text { Cell or neuron } \\
\text { number }\end{array}$ & $\begin{array}{l}\text { Age of animals and transgene(s) } \\
\text { harbored }\end{array}$ & Reference \\
\hline \multirow[t]{2}{*}{ Isotropic Fractionator } & $\begin{array}{l}\text { TgCRND8 } \\
(\mathrm{C} 3 \mathrm{H} / \mathrm{He}-\mathrm{C} 57 \mathrm{BL} / 6)\end{array}$ & \multirow[t]{2}{*}{ Whole brain } & \multirow[t]{2}{*}{$100.10 \pm 7.90 \times 10^{6}$} & \multirow[t]{2}{*}{6 months; K670M/N671L/N717F APP } & \multirow[t]{2}{*}{ Present study } \\
\hline & Dutch (C57BL/6J) & & & & \\
\hline Isotropic Fractionator & Swiss Webster & Whole brain & $108.90 \pm 16.25 \times 10^{6}$ & 2-5 months & [7] \\
\hline \multirow[t]{2}{*}{ Isotropic Fractionator } & TgCRND8 (C3H/He-C57BL/6) & \multirow[t]{2}{*}{ Cerebellum } & \multirow[t]{2}{*}{$43.92 \pm 2.78 \times 10^{6}$} & \multirow[t]{2}{*}{6 months; K670M/N671LN717F APP } & \multirow[t]{2}{*}{ Present study } \\
\hline & Dutch (C57BL/6J) & & & & \\
\hline Isotropic Fractionator & Swiss Webster & Cerebellum & $49.17 \pm 5.32 \times 10^{6}$ & 2-5 months & [7] \\
\hline $\begin{array}{l}\text { Isotropic Fractionator/ } \\
\text { Flow Cytometry }\end{array}$ & C57BI/6J & Cerebellum & $44.03 \pm 0.42 \times 10^{6}$ & $60-100$ days & [8] \\
\hline Isotropic Fractionator & TgCRND8 (C3H/He-C57BL/6) & Hippocampus & $\begin{array}{l}31.8 \% \text { decrease } \\
\text { in neurons }\end{array}$ & 6 months; K670M/N671LN717F APP & Present Study \\
\hline Isotropic Fractionator & Dutch (C57BL/6J) & Hippocampus & $\begin{array}{l}\text { No decrease in } \\
\text { neurons }\end{array}$ & 18 month Dutch E693Q APP mice & Present study \\
\hline Stereology & C57BL/6 & CA1 & $\begin{array}{l}\sim 25 \% \text { decrease } \\
\text { in neurons }\end{array}$ & $\begin{array}{l}\text { 14-18 month-old TgAPP23 } \\
\text { (K670M/N671L) mice }\end{array}$ & [9] \\
\hline \multirow[t]{2}{*}{ Stereology } & $\begin{array}{l}\text { APP/ PS1 }{ }^{M 146 L} \\
(C B A-12.5 \% \times C 57 B 16-87.5 \%)\end{array}$ & \multirow[t]{2}{*}{ CA1-CA3 } & \multirow[t]{2}{*}{$\begin{array}{l}\sim 30 \% \text { decrease } \\
\text { in neurons }\end{array}$} & \multirow[t]{2}{*}{$\begin{array}{l}17 \text { month } \operatorname{APP}\left(751^{S L}\right) \text { and presenilin } 1 \\
\left(P S 1^{\mathrm{M} 146 \mathrm{~L}}\right) \text { mice }\end{array}$} & \multirow[t]{2}{*}{ [10] } \\
\hline & Controls (C57BL/6) & & & & \\
\hline Stereology & $\begin{array}{l}\text { (C57BL/6 50\%-CBA } \\
25 \%-129 S V \text { 25\%) }\end{array}$ & $\mathrm{CA} 1 / 2$ & $\begin{array}{l}\sim 50 \% \text { decrease } \\
\text { in neurons }\end{array}$ & $\begin{array}{l}10 \text { month APPSLPS1KI (APP K670N/M671L, } \\
\text { and V717l; PS1 M233T/L235P knock-in) }\end{array}$ & [11] \\
\hline \multirow[t]{2}{*}{ Stereology } & \multirow[t]{2}{*}{ C57BL/6J } & \multirow[t]{2}{*}{ CA1 } & \multirow{2}{*}{$\begin{array}{l}33 \% \text { decrease } \\
\text { in neurons }\end{array}$} & 6 month APP/PS1KI & \multirow[t]{2}{*}{ [12] } \\
\hline & & & & $\begin{array}{l}\text { (APP K670N/M671L, and V717l; } \\
\text { PS1 M233T/L235P knock-in) }\end{array}$ & \\
\hline
\end{tabular}

$\mathrm{oA} \beta$, insoluble $\mathrm{fA} \beta$, and amyloid plaques, but not in Dutch mice that produce only oA $\beta$. It is evident that both $\mathrm{oA} \beta$ and $\mathrm{fA} \beta$ are toxic and implicated in the neurodegeneration process. However, various $A \beta$ species may impair neuronal function via different mechanisms, and clarification of this point merits further investigation.

\section{Methods}

\section{Animals}

Eight 6-month-old TgCRND8 APP K670N/M671L/V717F mice and seven wildtype littermates, as well as nine 18-month-old Dutch APP ${ }^{\mathrm{E} 639 \mathrm{Q}}$ mice and eight of their littermates were used in this study. These ages were chosen as previous studies demonstrated clear behavioral impairments and amyloid deposition in the TgCRND8 mice and intracellular accumulation in the Dutch mice at these time points [3,5]. All mice used in the current study were group-housed, given ad libitum access to food and water, and housed under a 12-hour light/dark cycle. All animal procedures were conducted in accordance with the National Institute of Health Guidelines for the Care and Use of Experimental Animals and were approved by the Institutional Animal Care and Use Committee of the Icahn School of Medicine at Mount Sinai.
Animals were perfused as previously described [17]. Brains were removed from the skull and postfixed in $4 \%$ PFA at $4^{\circ} \mathrm{C}$. Brains were weighed, cut into half, and further dissected into three regions, cerebellum, hippocampus, and neocortex and weighed. Results were multiplied by 2 to obtain estimates of cell numbers for the entire brain. In addition, brains were immunostained with the anti-amyloid monoclonal antibody 6E10 (Covance) as described in [15].

\section{Isotropic fractionator}

The isotropic fractionator is a fast and reliable technique for determining total cell and neuronal counts and cell densities in the brain. The procedure involves processing of highly anisotropic brain structures into homogeneous isotropic suspensions of cell nuclei that can be easily quantified [6]. Because the estimates of cell counts are obtained separately from the determination of brain volume, the two measurements can be used in comparative studies of brain-volume variation (i.e., comparing across species or between different mouse lines [6]). Briefly, postfixed samples were mechanically dissociated and homogenized in a solution of $40 \mathrm{mM}$ sodium citrate and $1 \%$ Triton X-100 as previously described [6]. The homogenates were collected and the homogenizer washed at least twice to collect any residual cells. To visualize nuclei 


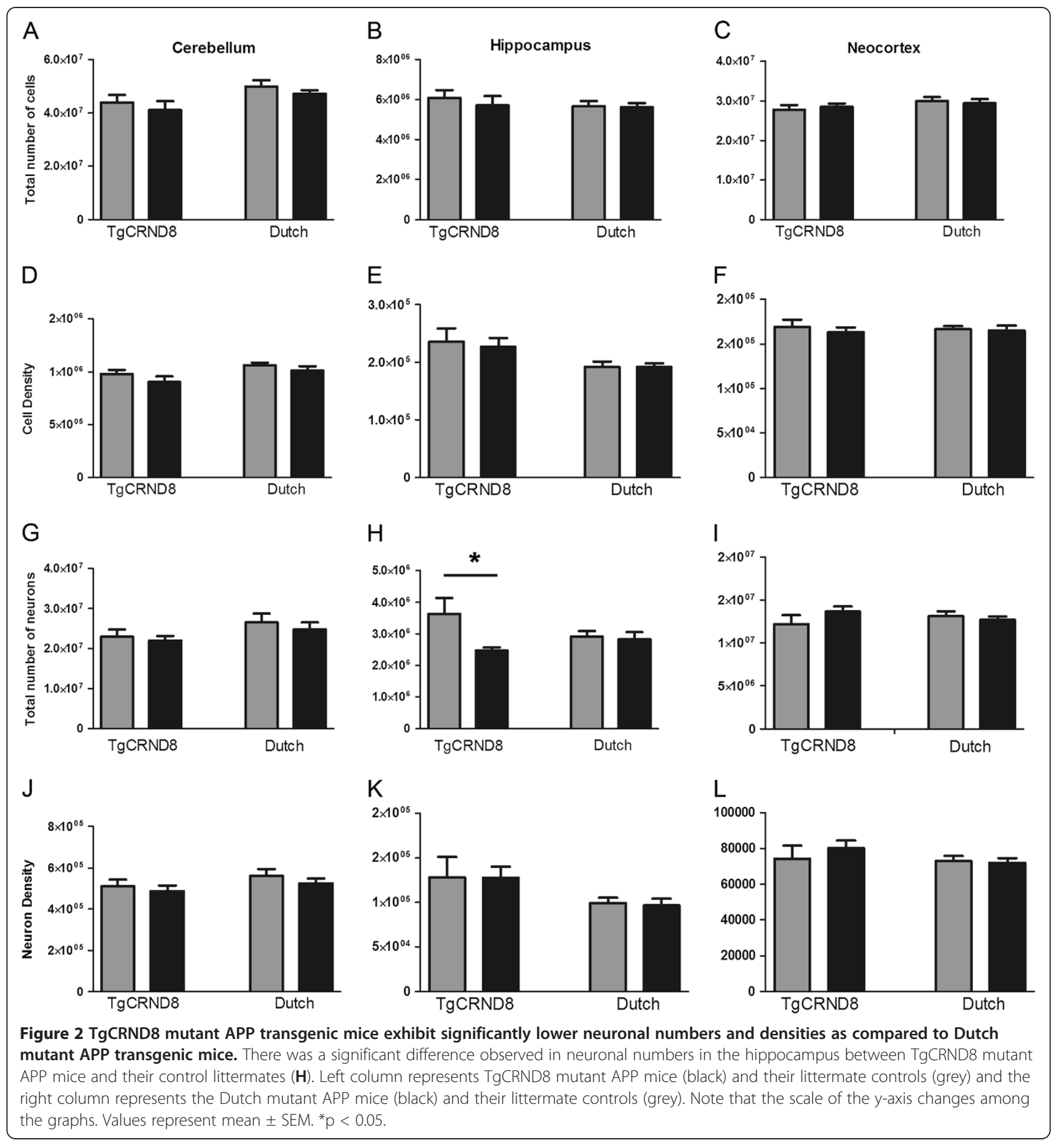

and obtain total cell counts, $1 \mu \mathrm{l}$ of 4,6-diamidino-2phenylindole (Sigma) was added to the cell suspension (volumes according to brain region; $10 \mathrm{ml}$ for cerebellum and neocortex, $3 \mathrm{ml}$ for hippocampus. The volume for each brain region was optimized so that at least 500 nuclei could be counted) To determine total neuron counts, $1 \mathrm{ml}$ of each cell suspension was removed, washed with PBS, and centrifuged for 10 minutes at $4000 \mathrm{x}$ g. Cells were then incubated in anti-NeuN antibody (1:200; Millipore) for 2 hours followed by incubation in a secondary antimouse IgG-Alexa-Fluor 594 for 1.5 hours (1:200; Millipore). Cells were then counted with a hemocytometer using a 20X/0.45 N.A., Plan-Apochromat objective on a Zeiss Axiophot microscope equipped with a motorized stage. All four quadrants in both the upper and lower grids of the hemocytometer were counted and averaged. Total cell numbers and neuronal numbers were calculated by multiplying the number of cells/ml by final volume. 
Densities were calculated by dividing the number of cells/ $\mathrm{ml}$ by the mass of brain region.

\section{Statistics}

All statistical analyses were performed using SPSS v19.0. Independent samples $t$-tests were used for comparison of TgCRND8 mutant APP or Dutch mutant APP mice to their respective littermates. Levene's test for homogeneity of variance was used for inclusion in parametric tests $(p>0.05)$. Significance for $t$-tests are reported with a $p$ value $<0.05$ using two-tailed tests with an $\alpha$ level of 0.05 . Values represent mean \pm SEM.

\section{Additional file}

Additional file 1: Table S1. Comparison between the DutchAPPE693Q mouse model and the TgCRND8APPK670N/M671LN7F mouse model [2-5].

\section{Abbreviations}

AD: Alzheimer's disease; A : Amyloid beta; APP: Amyloid precursor protein; PFA: Paraformaldehyde; PBS: Phosphate-buffered saline.

\section{Competing interests}

The authors have no competing interests.

\section{Author's contributions}

$H B$, JWS, PRH, and DLD all contributed to the writing of the manuscript. HB and DLD performed the isotropic fractionator and analyses. SG (with Dr ME Ehrlich, Icahn School of Medicine at Mount Sinai) created the Dutch APP mouse model and DW, PEF, and PHH created the TgCRND8 APP mouse model. SG and PRH supervised the project and edited the manuscript. All authors have read and approved the manuscript.

\section{Acknowledgements}

This work was supported by NIH grants P50 AG05138 (DLD, SG, PRH), P01 AG10491 (SG), and F31 AG039890 (HB). Support was also provided by the Canadian Institutes of Health Research (MOP-115056, PEF and PHH), Alberta Heritage Foundation for Medical Research (DW), and the Wellcome Trust, Medical Research Council, Howard Hughes Medical Institute, and Alzheimer Society of Ontario $(\mathrm{PHH})$. We would like to thank the members of the Ehrlich, Gandy, and Hof laboratories for help and discussion, and Dr Suzana Herculano-Houzel (Federal University of Rio de Janeiro) for introducing us to the isotropic fractionator. We would like to acknowledge Dr Camilla Butti (Icahn School of Medicine at Mount Sinai) for her help with optimizing the isotropic fractionator protocol.

\section{Author details}

${ }^{1}$ Fishberg Department of Neuroscience, Icahn School of Medicine at Mount Sinai, New York, NY 10029, USA. 'Friedman Brain Institute, Icahn School of Medicine at Mount Sinai, New York, NY 10029, USA. ${ }^{3}$ Department of Neurology, Icahn School of Medicine at Mount Sinai, New York, NY 10029, USA. ${ }^{4}$ Department of Psychiatry, Icahn School of Medicine at Mount Sinai, New York, NY 10029, USA. ${ }^{5}$ Alzheimer's Disease Research Center, Icahn School of Medicine at Mount Sinai, New York, NY 10029, USA. ${ }^{6}$ James J. Peters VA Medical Center, Bronx, NY 10468, USA. 'aboratory of Molecular and Cellular Neuroscience, Rockefeller University, New York, NY 10065, USA. ${ }^{8}$ Centre for Prions and Protein Folding Diseases, University of Alberta, Edmonton, AB T6G 2M8, Canada. ${ }^{9}$ Tanz Centre for Research in Neurodegenerative Diseases, Departments of Medical Biophysics and Medicine (Neurology), University of Toronto, Toronto, ON M5S 3H2, Canada. ${ }^{10}$ Cambridge Institute for Medical Research, University of Cambridge, Cambridge CB2 OXY, UK. ${ }^{11}$ Department of Neuroscience, Leon and Norma Hess Center for Science and Medicine, 10th Floor, 1470 Madison Avenue, New York, NY 10029, USA.
Received: 2 May 2012 Accepted: 18 September 2012

Published: 22 November 2012

\section{References}

1. Selkoe DJ: Alzheimer's disease results from the cerebral accumulation and cytotoxicity of amyloid beta-protein. J Alzheimers Dis 2001, 3:75-80.

2. Tomiyama T, Matsuyama S, Iso H, Umeda T, Takuma H, Ohnishi K, Ishibashi K, Teraoka R, Sakama N, Yamashita T, Nishitsuji K, Ito K, Shimada H, Lambert MP, Klein WL, Mori H: A mouse model of amyloid beta oligomers: their contribution to synaptic alteration, abnormal tau phosphorylation, glial activation, and neuronal loss in vivo. J Neurosci 2010, 30:4845-56.

3. Gandy S, Simon AJ, Steele JW, Lublin AL, Lah JJ, Walker LC, Levey Al, Krafft GA, Levy E, Checler F, Glabe C, Bilker WB, Abel T, Schmeidler J, Ehrlich ME: Days to criterion as an indicator of toxicity associated with human Alzheimer amyloid-beta oligomers. Ann Neurol 2010, 68:220-30.

4. Malthankar-Phatak GH, Lin YG, Giovannone N, Siman R: Amyloid deposition and advanced age fails to induce Alzheimer's type progression in a double knock-in mouse model. Aging Dis 2012, 3:141-55.

5. Chishti MA, Yang DS, Janus C, Phinney AL, Horne P, Pearson J, Strome R, Zuker N, Loukides J, French J, Turner S, Lozza G, Grilli M, Kunicki S, Morissette C, Paquette J, Gervais F, Bergeron C, Fraser PE, Carlson GA, George-Hyslop PS, Westaway D: Early-onset amyloid deposition and cognitive deficits in transgenic mice expressing a double mutant form of amyloid precursor protein 695. J Biol Chem 2001, 276:21562-70.

6. Herculano-Houzel S, Lent R: Isotropic fractionator: a simple, rapid method for the quantification of total cell and neuron numbers in the brain. J Neurosci 2005, 25:2518-21.

7. Herculano-Houzel $S$, Mota B, Lent R: Cellular scaling rules for rodent brains. Proc Natl Acad Sci U S A 2006, 103:12138-43.

8. Surchev L, Nazwar TA, Weisheit G, Schilling K: Developmental increase of total cell numbers in the murine cerebellum. Cerebellum 2007:1-6.

9. Calhoun ME, Wiederhold KH, Abramowski D, Phinney AL, Probst A, Sturchler-Pierrat C, Staufenbiel M, Sommer B, Jucker M: Neuron loss in APP transgenic mice. Nature 1998, 395:755-6.

10. Schmitz C, Rutten BP, Pielen A, Schafer S, Wirths O, Tremp G, Czech C, Blanchard V, Multhaup G, Rezaie P, Korr H, Steinbusch HW, Pradier L, Bayer TA: Hippocampal neuron loss exceeds amyloid plaque load in a transgenic mouse model of Alzheimer's disease. Am J Pathol 2004, 164:1495-502.

11. Casas C, Sergeant N, Itier JM, Blanchard V, Wirths O, van der Kolk N, Vingtdeux V, van de Steeg E, Ret G, Canton T, Drobeca H, Clark A, Bonici B, Delacourte A, Benavides J, Schmitz C, Tremp G, Bayer TA, Benoit P, Pradier L: Massive CA1/2 neuronal loss with intraneuronal and N-terminal truncated Abeta42 accumulation in a novel Alzheimer transgenic model. Am J Pathol 2004, 165:1289-300.

12. Breyhan H, Wirths O, Duan K, Marcello A, Rettig J, Bayer TA: APP/PS1KI bigenic mice develop early synaptic deficits and hippocampus atrophy. Acta Neuropathol 2009, 117:677-85.

13. Lublin AL, Gandy S: Amyloid-beta oligomers: possible roles as key neurotoxins in Alzheimer's Disease. Mt Sinai J Med 2010, 77:43-9.

14. Tomic JL, Pensalfini A, Head E, Glabe CG: Soluble fibrillar oligomer levels are elevated in Alzheimer's disease brain and correlate with cognitive dysfunction. Neurobiol Dis 2009, 35:352-8.

15. Lefterov I, Fitz NF, Cronican A, Lefterov P, Staufenbiel M, Koldamova R: Memory deficits in APP23/Abca1+/- mice correlate with the level of Abeta oligomers. ASN Neuro 2009, 1.

16. Gouras GK, Tampellini D, Takahashi RH, Capetillo-Zarate E: Intraneuronal beta-amyloid accumulation and synapse pathology in Alzheimer's disease. Acta Neuropathol 2010, 119:523-41.

17. Dickstein DL, Brautigam H, Stockton SD Jr, Schmeidler J, Hof PR: Changes in dendritic complexity and spine morphology in transgenic mice expressing human wild-type tau. Brain Struct Funct 2010, 214:161-79.

doi:10.1186/1750-1326-7-58

Cite this article as: Brautigam et al:: The isotropic fractionator provides evidence for differential loss of hippocampal neurons in two mouse models of Alzheimer's disease. Molecular Neurodegeneration 2012 7:58. 